\title{
EPHREM'S MADROSHE AND THE SYRIAN ORTHODOX BETH GAZO A LOOSE, BUT FASCINATING, AFFINITY
}

\author{
GREGORIOS Y. IBRAHIM \\ SYRIAN ORTHODOX ARCHBISHOP OF ALEPPO \\ MARDIN-EDESSA PUBLISHING HOUSE \\ ALEPPO, SYRIA \\ GEORGE A. KIRAZ \\ BELL LABORATORIES \\ MURRAY HiLL, NEW JERSEY
}

\section{INTRODUCTION}

[1] St. Ephrem is probably the most celebrated saint of the Syriac Church. His hymnal literature, produced prior to the Christological controversies of the fifth century, were inherited by the Syriacspeaking church, East and West, along with a musical tradition. The extent to which Ephrem's hymns are preserved in the hymnal literature is difficult to ascertain as a great number of the liturgical texts attributed to the saint are in fact of a later age. It is even more difficult to pass any judgment on the musical tradition that was associated with Ephrem's hymns.

Our objective in this brief outline is a modest one. We do not intend to study the poetic structure of Ephrem's hymns nor do we intend to propose a theory of musical tradition. Such work is 
beyond the knowledge of the authors and will be best evaluated by capable scholars and musicologists. What we wish to do here is to point out some of the qole "melodies" in Ephrem's genuine madroshe which correspond to known melodies in the Syrian Orthodox Beth Gazo, the church's musical resource. Further, we demonstrate, in a recorded form [all recordings are in the online edition], how such qole may be chanted according to melodies that have been in practice in the Syrian Orthodox Church for many a generation.

No implication is made that the melodies recorded here are identical, or even similar, to the ones practiced by the saint himself or his pupils. The mere fact that a modern cleric can pick up a genuine piece written by St. Ephrem in the fourth century, recognize its qolo, and chant it with that qolo's melody that is known to him with ease is fascinating in its own right. Our modest effort may indicate a link, no matter how loose, between Ephrem's melodies and those of the Beth Gazo.

We start with a brief description of the Beth Gazo system. We then point out a number of the qole employed in Ephrem's madroshe (based on Beck's edition in the CSCO) which correspond to qole in the Beth Gazo. Finally, we give recordings of Ephrem's genuine texts chanted with the corresponding melodies of the Beth Gazo. It is hoped that this modest work will generate scholarly interest in Syriac sacred music.

\section{THE BETH GAZO AND ITS SYSTEM}

The Beth Gazo is a liturgical book that constitutes a reference to Syrian Orthodox music, without which the cleric cannot perform any liturgical duties. The actual title of this book varies in modern editions: beth gazo dqinotho, ${ }^{1}$ dazmirotho ${ }^{2}$ or dne "motho ${ }^{3}$ "Treasury of Melodies," "Songs" or "Chants."

How is the Beth Gazo used? Each hymn in the entire Syrian Orthodox liturgical system is associated with what one might call a "title", or more accurately a heading that indicates the melody with which the hymn is to be chanted. The title is usually of the form ${ }^{e}$ al

${ }^{1}$ Dolabani's first edition of 1913. See the bibliography for a complete list of editions.

${ }^{2}$ Konat's edition of 1986.

${ }^{3}$ Çiçek's republication of Dolabani’s edition, 1981, 1985 and 1995. 
qolo $d$-... "as the melody of..." and has little, if anything, to do with the subject matter of the hymn itself. The Beth Gazo contains a listing of all such qole. Under each qolo, melodies of eight different modes are given, analogous to the eight-mode Gregorian chant system. To add to the richness of this system, some modes have variants of their own called sublophe-only the skilled can master them. The melodies are not documented using musical notation; rather, by texts that the cleric associates with melodies learned by tradition. Sublophe, on the other hand, are not documented but are transmitted orally from malphono to talmidho. An experienced cleric, of course, need not consult the Beth Gazo. He would have already memorized the hundreds of texts it contains along with their respective melodies including shublophe. Such music masters, alas, are hard to come by today!

Earlier versions of the Beth Gazo contained thousands of melodies. Barsoum ${ }^{4}$ laments the loss of a "huge and rare" manuscript of the Monastery of St. Abraham in Midyat, due to the turbulent years of the First World War during which the Syrian Orthodox faithful were under much persecution. A few manuscripts representing portions of the original Beth Gazo survive and were used in a modern edition. ${ }^{5}$ Today, at most a thousand melodies survive. These are gathered in an abridged version initially published by Dolabani ${ }^{6}$ in 1913 . We lament the fact that some of the melodies in the abridged version are unknown and presumed lost.

The abridged version of the Beth Gazo consists of the following types of hymns (the term "hymn" is used here loosely and does not indicate a madrosho):

1. Qole shabroye "vigils." It is not clear what the term shahroye refers to. According to Barsaum, ${ }^{7}$ either such qole were originally sung during vigil hours (shabro), or they were sung by a group of people belonging to the order of shahroye "vigilants" (the same term is used in Latin, vigiles). The first two modes are

${ }^{4}$ A. Barsaum, kitaab al-lulu al-manthur, 118.

5 Y. Çiçek, beth gazo rabo, 1992. This edition is mainly based on a manuscript which originates from Adyaman, Turkey.

${ }^{6}$ Y. Dolabani, kethobo qpiso dbeth gazo, 1913.

${ }^{7}$ A. Barsaum, kitaab al-lulu al-manthur, 114. 
dedicated to the Virgin, the 3rd and 4th to the saints, the 5th and 6th to penitence, and the 7th and 8th to the departed.

2. Gushmo (pl. gushme) "body" each of which consists of eight modes. These are recited during the daily offices known as šhimo.

3. Sebeltho (pl. seblotho) dmadroshe "ladder." It is this category that seems to have mostly inherited Ephrem's madroshe tradition. Two of these follow the eight-mode system. The rest have one melody each.

4. Phardo (pl. Pharde) "single." These are short hymns divided into eight collections corresponding to the eight modes. Within each collection, each hymn has its own invariant melody.

5. Qonuno yawnoyo (pl. qonune yawnoye) "Greek canon". These are divided into eight collections corresponding to the eight modes as well.

6. Mawrbo (pl. mawrbe) "magnificat." Dedicated to the Virgin Mary, these are divided into eight collections corresponding to the eight modes.

7. Qole ghnize "mystic hymns." They exist in the printed edition in eight modes; the melodies of most seem to be lost, alas!

8. Takheshphotho rabuloyotho "litanies of Rabula." Attributed to Rabula, these are divided into eight collections corresponding to the eight modes.

9. Tborto (pl. tborotho) "broken." They fall into three categories: those attributed to St. Jacob [of Serug], St. Ephrem and of St. Balay. Each of them follows the eight-modal system.

10. Quqlion (pl. quqalya) "cycles." These are cycles from the Psalms and follow the eight-modal system.

What makes the Beth Gazo even richer is the existence of various schools of music within the Syrian Orthodox tradition. Two main traditions are identified: East and West. The former represents the school of Tagrit and is only known to the Syrian Orthodox of modern day Iraq. The latter is practiced by the rest of the Syrian Orthodox Church and, in turn, has its own schools of music.

Of the Western schools, the School of Mardin is by far the most popular and is considered the norm. This is due to the fact that for hundreds of years, the patriarchal seat was located at Deir 
al-Zafaran near Mardin. The second largest school (in terms of practice) is that of Tur 'Abdin. Presently, it is used in Tur 'Abdin and in the Diaspora with communities originating from that region. Another tradition, which is preserved to some extent, is that of the School of Edessa. It is mainly used today among the Edessan community, presently living in Aleppo, Syria. Diarbaker (in Turkey) and Sadad (a village in Syria) have their own traditions as well; the former is not preserved well enough. The school of Harput (in Turkey) is another endangered tradition. With its inhabitants scattered in the four corners of the world with no substantial community in one particular place, it is only preserved in a recording made by the late Cor-Episcopos Abd al-Nur Samuel of Harput. India has developed its own tradition, which one might call the Malankara school of music; this tradition may have been derived from the school of Mardin. ${ }^{8}$

Syriac music suffers from the lack of scholarly attention. H. Husmann ${ }^{9}$ published, in musical notation, the body of shbimo and qole shahroye based on recordings by the late archbishop Mor Cyril (Qorillos) Jacob for the former and his brother Malphono Asmar Khouri for the latter. Recently, G.Y. Ibrahim published the tradition of Mardin, also in musical notation made by Nuri Iskandar ${ }^{10}$ of Aleppo, based on recordings made by the late Patriarch Jacob III in 1960. A similar publication of the Edessan tradition is imminent. The recordings of Jacob III were recently digitized and placed on the Internet by Syrian Orthodox Resources and the Syriac Computing Institute. (For other works, see the bibliography.)

\section{MELODIES OF EPHREM's MADROSHE}

[12] We have examined the following cycles of Ephrem's madroshe based on Beck's edition: Contra Haereses $(\mathrm{CH})$, Contra Julianum (CJ), Carmina Nisibena (CNis), Ecclesia (Eccl), Epiphania (Epiph), Fide, Ieiunio (Ieiuni), Nativitate (Nat), Paradiso (Par), Virginitate (Virg). We found that the following qole have corresponding counterparts, in name and poetic structure in most cases, in the Beth Gazo (qole

${ }^{8}$ G. Kiraz, an overview of the Beth Gazo on the Syrian Orthodox Resources web site.

${ }^{9}$ H. Husmann, Die Melodien der Jakobitischen [sic] Kirche, 1996, 1971.

${ }^{10}$ Nuri Iskandar, beth gazo bnota, 1992. 
marked with $*$ are illustrated with a recording in the online edition of this paper):

1. Ir sa (CH, Eccl, Ieiuni)*.

2. Limi loa احما مل (Epiph)*.

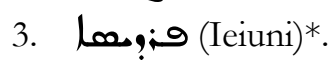

4. مخد مخحا (CNis, Virg).

5. أو (CH, Nat, Virg)*.

6. .

7. . of or (Nat).

It is interesting to note that all of the above hymns fall within the madroshe category of the abridged Beth Gazo. Further, they occur almost adjacent to each other, though this might be a mere coincidence. The madroshe section of the Beth Gazo starts with the above qole in the order given, except that there is another qolo (مחס on a a between items 2 and 3. The last item above is the 35th madrosho in the abridged Beth Gazo. The entire madroshe corpus of the abridged Beth Gazo consists of 54 madroshe.

To the disappointment of the modern cleric, the vast majority of Ephrem's qole are not present in the abridged Beth Gazo and, hence, their melodies cannot be recognized. Of the above mentioned cycles, the following qole belong to this category:

1. م: of (Fide).

2. . 1,00 of (CNis).

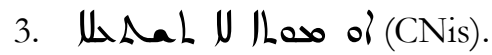

4. .

5. INaعo, läة of (Eccl).

6. .

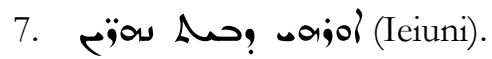

8. La lis (CNis, Fide).

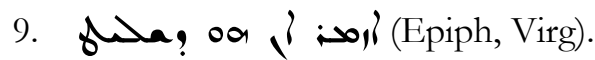


10. أتس أحةد محتس هلحس (Virg).

11. أنتس oأنتس (CH).

12. أنتس رمن: (Epiph).

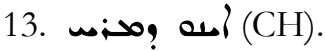

14. أس (Eccl, Fide).

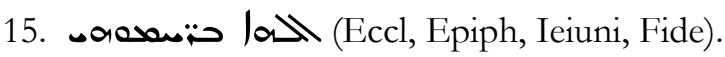

16. الحها ginم (CNis, Eccl, Epiph, Virg).

17. الح (CH).

18. اللف الحونت (Nat.)

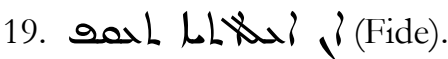

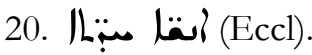

21. .

22. Ia (CJ).

23. أهم (CH, CNis, Eccl, Virg).

24. أi (Nat).

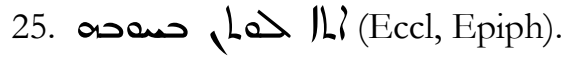

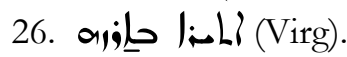

27.

28. حساه حمه حصن (CNis, Fide, Nat).

29. (Eccl).

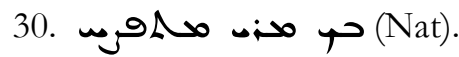

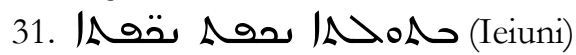

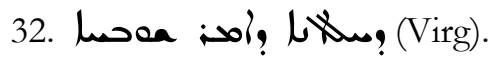

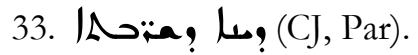

34. ملم " (CNis).

35. أحم ملح (Epiph).

36. Loe La (Eccl, Epiph, Nat).

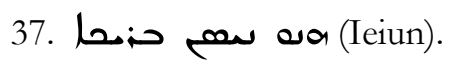


38. مخه ح: (CH, Fide).

39. مسما gisis).

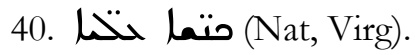

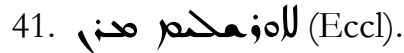

42. مخحا aمسل aمe aris).

43. oגuil (Virg).

44. مسه مפم لمصله (CH, Fide, Nat).

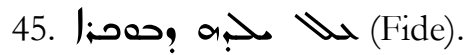

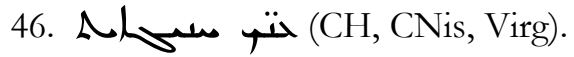

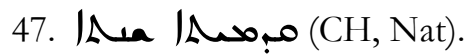

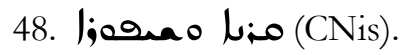

49. مسنه وحن (CH, Fide).

50. liah (CNis, Epiph, Fide).

[15] It is also interesting to note that while the entire Paradiso cycle

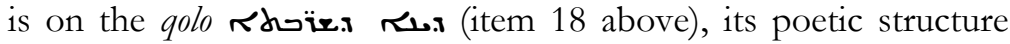
matches that of the madrosho roo.xis of the Beth Gazo and the entire cycle can be chanted using the eight melodies of this qolo.

\section{RECORDINGS}

[16] [The online edition provides madroshe from the genuine writings of St. Ephrem chanted according to the melodies of their corresponding hymns in the Beth Gazo. For each melody, we give Ephrem's text from Beck's edition with a recording in the voice of Metropolitan Gregorios Y. Ibrahim of Aleppo.]

\section{CONCLUSION}

[18] We demonstrated in this brief outline a somewhat loose, but fascinating, connection between Ephrem's madroshe and modern practice of the Syrian Orthodox Beth Gazo. To what extent did Ephrem's music influence the Syriac-speaking Church and how much of that is still preserved still awaits investigation. There are numerous factors that complicate this matter. For example, the qole titles that appear in Beck's edition may be a later addition to 
Ephrem's composition. The manuscript tradition needs to be further investigated in this regard.

In 1994, Brock (with Alison Salvesen reciting with him) demonstrated at the SEERI conference in India how Ephrem's sugyotho may be used today by the church in religious plays. Along a similar line, the poetic structures of Ephrem's madroshe can be compared with those of the existing hymns of the various Syriac Churches. Traditional melodies can be applied to Ephrem's genuine work in this manner giving the Syriac-speaking Church an opportunity to taste the fruits of its forefathers. An edition of Ephrem's work for "public consumption" that indicates to the modern cleric how to chant the hymns would be highly desirable indeed.

\section{BIBLIOGRAPHY}

Barsoum, I. كتاب اللرلؤ المنثور في تاريخ العلوم والآداب السريانية (Aleppo, 19572).

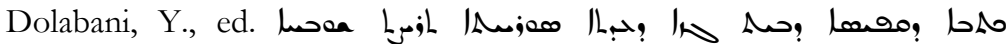
(Mardin, 1913', 1925², 19603; Losser, 19814, 19855 , 19956).

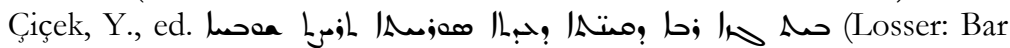
Hebraeus Verlag, 1992).

Dinno, N. “الموسيقى و الألحان السريانية")" lisaan al-mashriq, vol. 1 (1948): 24-8, 32-7, 34-8.

Husmann, H. Die Melodien der Jakobitischen Kirche, transkribiert und herausgegeben. Die Melodien des Wochenbreviers (Šbimta) (Wien: Hermann Böhlaus Nachf., 1969).

Husmann, H. Die Melodien der Jakobitischen Kirche, transkribiert und herausgegeben. Die Qale Gaoanaie des Beith Gaza (Wien: Hermann Böhlaus Nachf., 1971).

Ibrahim, G.Y. Syriac Music (Aleppo: Mardin Publishing, 1996). [In Arabic.] Jeannin, O.S.B. Mélodies Liturgiques, Syriannes et Chaldéennes (Paris: vol. 1, 1924; vol. 2, 1928).

Kasrawani, I. Le Beth Gazo et L'Octoichos dans la Liturgie Sévérienne [sic], diss. (Universitè de la Sorbonne, 1994). [Not published.]

Kiraz, G. Beth Gazo Dne motho, The Treasury of Chants, (Syrian Orthodox Resources web site [http://sor.cua.edu], 1997). [Contains a digitized recording of the Beth Gazo chanted by Patriarch Jacob III.]

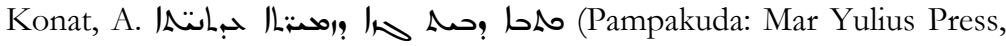
1986). [The organization of this Beth Gazo differs from Dolabani's edition. It is not clear whether this is a reprint of an earlier edition.] 
Malacrida, G. Forme del Canto Siriaco, Ph.D. Dissertation (Universita'degli Studi di Bologna, 1993).

Nuri, I. حم (Aleppo: Al-Raha Publishing House, 1992). [In musical notations.]

Raes, A. Liturgiam Orientalem, Introduction (Rome, 1947).

Sowmy, I. Mardutho Dsuryoye, Evolução Cultural dos Povos Assirio-Arameos do Oriente. vol. 10, a Musica (São Paulo, 1989). 